\title{
Spatial and Seasonal Variations of Organic Carbon-Based Nutrients in Setiu Wetland, Malaysia
}

(Variasi Bermusim dan Reruang Nutrien Berasaskan Karbon di Tanah Bencah Setiu, Malaysia)

\author{
SUHAimi SURATMAN*, NUR HAYATI CHE ZAN, AZYYATI AbDUl AZIZ \& NORHAYATI MOHD TAHIR
}

\begin{abstract}
The aim of this study was to assess spatial and seasonal variations of dissolved and particulate organic carbon (DOC and POC, respectively) in the Setiu Wetland, which is located in the southern region of the South China Sea coastal area. Surface water samples were collected monthly from October 2009-September 2010. In addition, the concentration of chlorophyll-a was determined. The DOC and POC mean concentration varied between 80-340 $\mu \mathrm{M}$ and 60-115 $\mu \mathrm{M}$, respectively. The results showed that the concentrations of these parameters were mainly influenced by human activities and season. Higher concentrations of DOC $(150-340 \mu \mathrm{M})$ and $P O C(75-115 \mu \mathrm{M})$ were found at stations near the populated area, aquaculture and palm oil plantation. In addition, higher concentrations of DOC (200-275 $\mu \mathrm{M})$ and POC (105-150 $\mu M)$ were also recorded during the monsoon season due to runoff from terrestrial sources and resuspension from bottom sediments. No significant correlation between the low molecular weight (LMW) fractions of DOC and chlorophyll-a $\left(R^{2}=0.0096, \mathrm{p}>0.05\right)$ further supports the hypothesis that phytoplankton not playing key role in regulating the organic carbon distribution. Higher percentage of LMW DOC in monsoon season suggesting possible input of this fraction from land runoff to the wetland area.
\end{abstract}

Keywords: Dissolved organic carbon; particulate organic carbon; Setiu Wetland (Malaysia); spatial and seasonal variations, surface water

\section{ABSTRAK}

Kajian ini dijalankan untuk menilai variasi bermusim dan reruang karbon organik terlarut dan partikulat (masingmasing DOC dan POC) di Tanah Bencah Setiu, yang terletak di kawasan perairan selatan Laut China Selatan. Sampel air permukaan dikumpulkan secara bulanan dari Oktober 2009-September 2010. Sebagai tambahan, kepekatan klorofil-a juga ditentukan. Purata kepekatan DOC dan POC masing-masing berubah antara 80-340 $\mu \mathrm{M}$ dan 60-115 $\mu \mathrm{M}$. Keputusan kajian menunjukkan kepekatan parameter ini dipengaruhi terutamanya oleh aktiviti manusia dan musim. Kepekatan DOC (150-340 $\mu M)$ dan POC (75-115 $\mu$ M) yang tinggi direkodkan di stesen yang berhampiran dengan kawasan yang ramai penduduk, akuakultur dan perladangan kelapa sawit. Tambahan lagi, kepekatan DOC (200-275 $\mu$ M) dan POC (105-150 $\mu M)$ adalah tinggi semasa musim monsun disebabkan oleh larutlesap daripada sumber daratan dan ampaian dari sedimen dasar. Tidak terdapat korelasi signifikan antara fraksi DOC yang mempunyai berat molekul rendah (LMW) dan klorofil-a $\left(R^{2}=0.0096, \mathrm{p}>0.05\right)$ yang seterusnya menyokong hipotesis bahawa fitoplankton tidak memainkan peranan penting dalam mengawal taburan karbon organik. Peratusan LMW DOC yang tinggi semasa musim monsun mencadangkan kemungkinan input fraksi ini dari larutlesap daratan ke kawasan tanah bencah.

Kata kunci: Air permukaan; karbon organik partikulat; karbon organik terlarut; Tanah Bencah Setiu (Malaysia); variasi bermusim dan reruang

\section{INTRODUCTION}

Rivers are major channels for the transport of terrestrial organic matter to the coastal marine environment (Cai et al. 2012; Meybeck 1982). It was estimated by Meybeck (1982) that almost $0.4 \times 10^{15} \mathrm{~g}_{\text {year }}{ }^{-1}$ of organic carbon is discharged to the ocean by the world rivers. Study has underlined that in open ocean and marginal seas, both dissolved and particulate organic carbon (DOC and POC, respectively) play important role in biogeochemical processes and the cycle of carbon (Hung et al. 2007). According to Graham et al. (2001), the main source of the organic matter to the marine environment is allochthonous materials exported from the land through rivers and autochthonous production of organic matter through photosynthesis by algae and intertidal vegetation. On the other hands, it is also from the allochthonous marine materials itself (Goñi et al. 2003). The quantity and quality of the organic material especially particulate organic matter (POM) produced by phytoplankton depend on nutrient status of the natural waters, phase of growth and phytoplankton composition (Fernandes et al. 2009). It is likely that the organic carbon (especially DOC) from these environments has significant effects on surf zone biogeochemistry and potentially affecting the oxygen concentrations in marine environment (Avery et al. 2012). 
In this study, we focus on investigating the distribution of DOC and POC in the Setiu Wetland. The wetland which covers many ecosystems such as estuary, mangrove, wetland and lagoon is located at Setiu-Chalok-BariMerang River basin, Peninsular Malaysia (WWF 2008). The main activities within it are predominantly agricultural (palm oil plantation), aquaculture (brackish water cage culture, pond and pen culture and oyster farming) and activities involving seafood-based product. In addition, there is also small jetty for boating activities in this area. As a result, many pollutants and associated waste products from these activities have been found in the wetland through runoff and direct inputs (Suratman et al. 2012). Thus it is important to understand the cycling of DOC and POC in this wetland, the factors controlling it because wetlands are vulnerable and under pressure and we need to understand human impacts on this wetland with respect to these two particular nutrients.

\section{MATERIALS AND METHODS}

Ten sampling stations (S1-S10) were selected to cover various wetland environments as shown in Figure 1. The samples were collected monthly for one year during the same tidal condition i.e. at high water ( $\sim 1.5 \mathrm{~m}$ depth). This sampling time was necessary since this allowed samples to be collected at the upstream stations as most of the stations cannot be reached during the low water. This sampling strategy allows comparison between monsoon (OctoberDecember 2009) and post monsoon (January-September
2010) conditions. The water samples were collected at 0.5 $m$ depth below the surface water using a Van Dorn sampler. During the sampling trip, the samples were stored in $1 \mathrm{~L}$ high density polyethylene (HDPE) bottles and stored in a cooler $\left(-4^{\circ} \mathrm{C}\right)$ during transportation to the laboratory.

Upon arrival at the laboratory, the samples were immediately vacuum filtered through a precombusted $\left(450-500^{\circ} \mathrm{C} ; 4 \mathrm{~h}\right) 0.7 \mu \mathrm{m}$ pore size Whatman $\mathrm{GF} / \mathrm{F}$ glass fibre filter. The dissolved fraction was used for DOC determination whereas the particulate fraction was used for POC analysis.

Concentration of DOC was determined by the high temperature catalytic oxidation (HTCO) method with a Shimadzu TOC-VCPH analyzer. Calibration of the instrument was performed by running freshly prepared standards of potassium hydrogen phthalate $\left(\mathrm{KHC}_{8} \mathrm{H}_{4} \mathrm{O}_{4}\right)$. The samples were thawed and acidified to $\leq 2$ by adding $100 \mu \mathrm{L}$ of $10 \%$ of $\mathrm{HCl}$ to $20 \mathrm{~mL}$ sample, then sparged with $\mathrm{N}_{2}$ gases for 8 min in order to eliminate the $\mathrm{CO}_{2}$ gas formed as a result of reaction between inorganic $\mathrm{C}$ in the sample and $\mathrm{HCl}$ added, allowing DOC only analysis. After that, sample was injected onto the combustion column filled with catalyst $\left(\mathrm{Al}_{2} \mathrm{CO}_{3}\right.$ impregnated $0.5 \%$ platinum) at $680^{\circ} \mathrm{C}$ and measured by non-dispersive infrared (NDIR). In order to ensure the efficiency and reliability of this method, the Certified Reference Materials (CRMs) i.e. Low Carbon Water (LCW) and Deep Seawater (DSR) obtained from the Hansell's Laboratory, University of Miami were also run during samples analysis (Badr et al. 2003; Suratman et al. 2009). The consensus values for

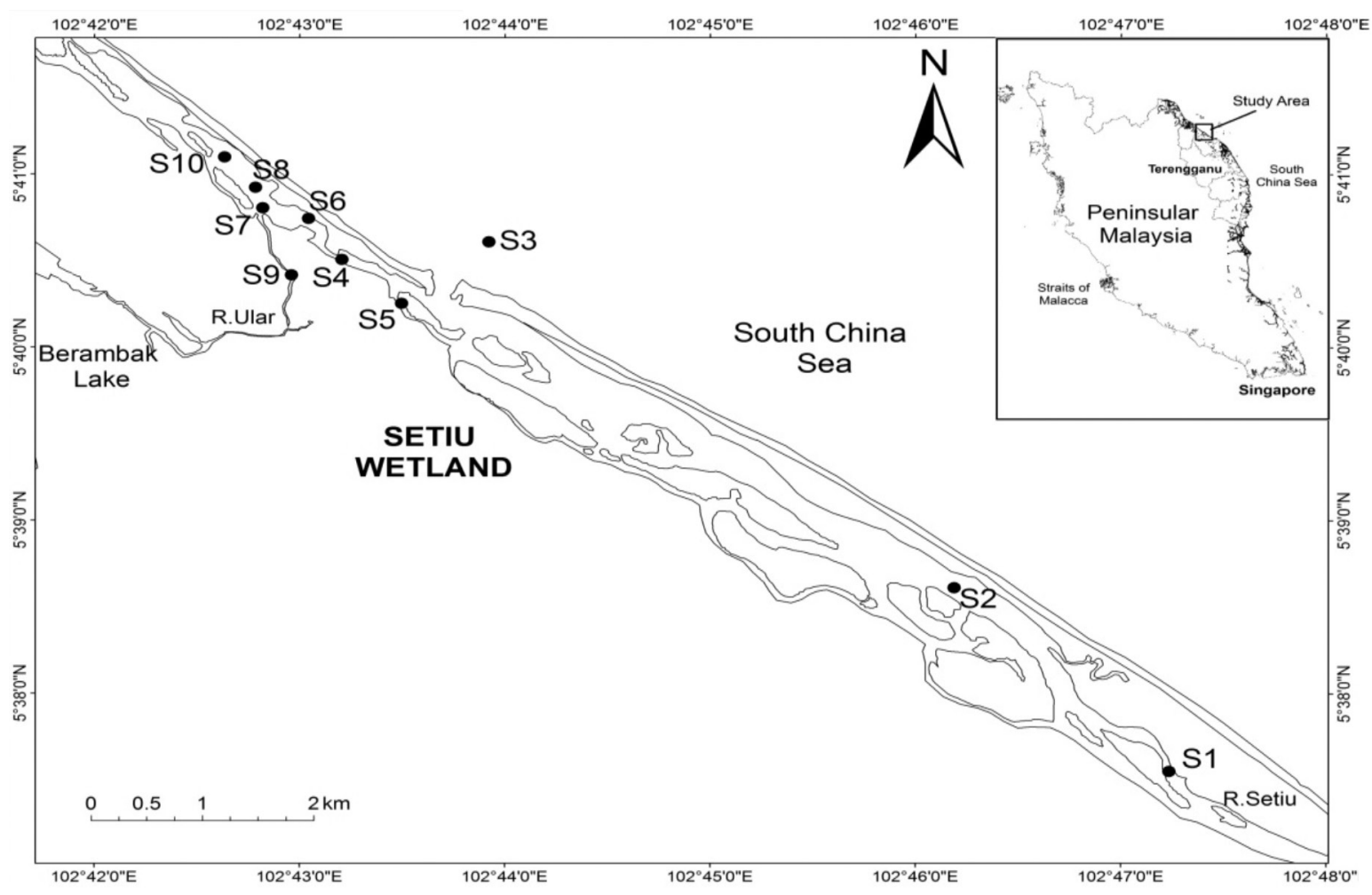

FIGURE 1. Location of the sampling stations in Setiu Wetland 
the LCW and DSR for DOC concentrations were 1-2 $\mu \mathrm{M}$ and 44-46 $\mu \mathrm{M}$, respectively. The LCW and DSR values obtained in this study were range from $0-0.96 \mu \mathrm{M}$ (mean $0.34 \pm 0.54 \mu \mathrm{M}, \mathrm{n}=10$ ) and 41.2-48.9 $\mu \mathrm{M}$ (mean $43.9 \pm$ $8.9 \mu \mathrm{M}, \mathrm{n}=10)$. The instrument used $\geq 3$ injections per analysis to achieve a precision of $<5 \%$.

The measurement of POC was carried out using a Thermo EA1112 CHNS analyser through HTCO method (Bennett et al.2011; Suratman et al. 2009). The acetanilide was used as a calibration standard. This method is based on the removal of inorganic carbon forms by acid leaching before the measurement of organic carbon content. Fifty $\mathrm{mL}$ of sample was filtered and the particulate matter collected. The particulate materials were then transferred into the polycarbonate petri dishes using stainless steel tweezers and dried in an oven for $60^{\circ} \mathrm{C}$ for $24 \mathrm{~h}$ then stored until analysis. Particulate samples were then fumed with concentrated $\mathrm{HCl}$ for 30 min to remove inorganic carbon and then cut into appropriate size. Then, it was folded into the tin capsule before running through the CHNS analyzer. The precision of analysis was $<5 \%$ based on the duplicate samples.

Besides DOC and POC, the concentration of chlorophyll- $a$ (chl- $a$ ) was also determine based on a standard method (APHA 1998). In addition, some of the DOC samples was also fractionated using membrane ultrafiltration in a stirred cell (Amicon) under nitrogen pressure. The low molecular weight (LMW) DOC in this study was operationally defined as the fractions with sizes below $30 \mathrm{kDa}$. The LMW DOC fraction was then analysed using the HTCO method as described previously.

\section{RESULTS AND DISCUSSION}

\section{SPATIAL AND SEASONAL DISTRIBUTION OF DOC AND POC}

We consider first the annual mean concentrations and the distributions of DOC and POC in surface waters as shown in Figure 2. In this study, the DOC and POC mean concentrations varied for each station in the range of 80$340 \mu \mathrm{M}$ and 60-115 $\mu \mathrm{M}$, respectively. Based on the ANOVA test two-factor without replication, the concentrations of both parameters were significant different $(p<0.05)$ between sampling stations and sampling dates. In general, DOC and POC showed higher concentration at stations S1 (downstream of Setiu River), S9 (downstream of Ular River) and also at the aquaculture area (S5, S6, S7, S8 and S10). It was expected that higher concentration of DOC and POC at station S1 might be from the terrestrial origin or derived from untreated waste water from the populated zone further upstream in the Setiu River. Lobbes et al. (2000) have shown that DOC will be released from soil or within the water column during the degradation of terrestrial and riverine organic matter. In addition, study by Wu et al.(2007) in the Yangtze estuary, China showed that the higher POC in their study area were from riverine suspended organic matter and plantations. Contribution from urban area to increase the POC concentration in the water column was also found in the vegetation-rich Nagara River, Japan (Li et al. 2005). Hence, clearly freshwater inputs are a significant source of DOC and POC.

For the stations which located at the aquaculture area (S5, S6, S7, S8 and S10), DOC concentrations are elevated and we suggest the sources of DOC and POC is mainly from food pellets that used at the fish farms and from fish feaces (Li et al. 2005). According to McKinnon et al. (2010), the leaching of DOC from food pellets used in fish farms and from fish feaces contributed to the presence of DOC into the water column. This was supported by Jover et al. (2007) in their study around the Mediterranean fish farms. They found that the leaching of DOC from fish feaces was generally higher compared to food pellets. They stated that uneaten food pellets start leaching their nutrients as soon as they were introduced into the water column. The nutrients were then rapidly eaten by fishes thus excreting the organic $\mathrm{N}$ and $\mathrm{C}$ in the water column. In addition, $\mathrm{Gao}$ et al.(2005) found that the accumulation of uneaten feed and faeces from fish cages forms the flocculent black 'fish farm sediment' under fish rafts, reflecting the presence of high level of organic content. Thus consistent with these other studies, fish farms appear to be an important source of DOC and POC.
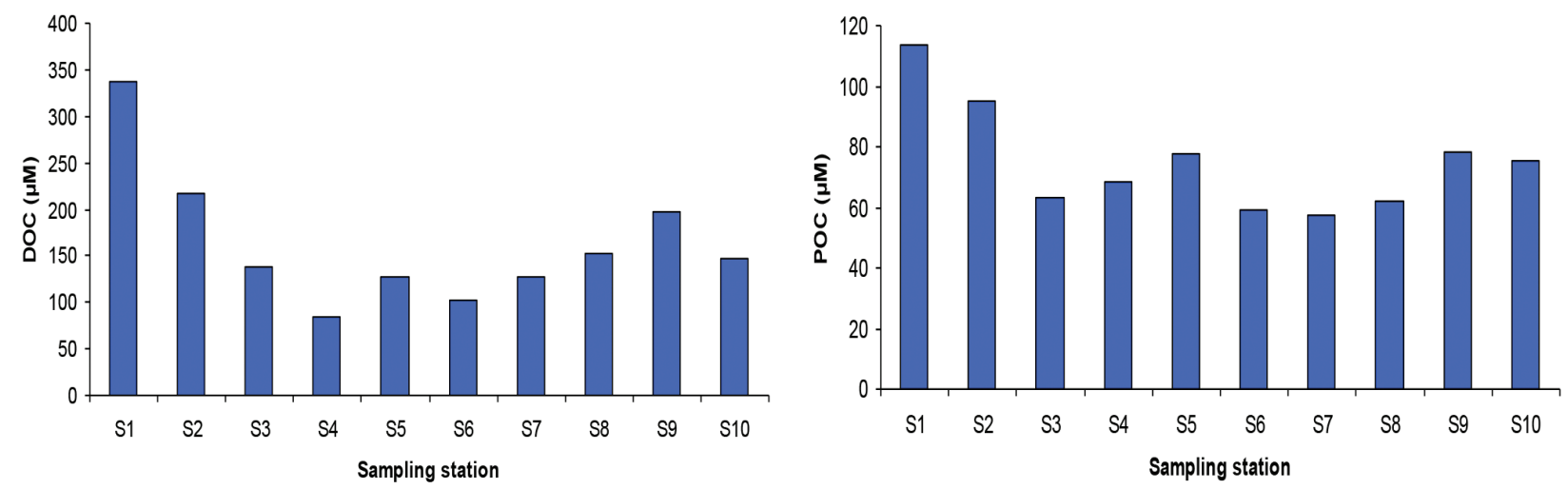

FIGURE 2. Variation of mean DOC and POC concentrations for each sampling station 
The high concentrations of DOC and POC at station S9 may be due to inputs from the palm oil plantation at the upstream of Ular River since there is no urban settlement to provide the source. Study by Graeber et al. (2012) suggested that agricultural areas consistently exported high DOC concentrations to the river system, higher than the forested catchments and similar to those from wetland catchments. This was probably due to the used of organic fertilizers in the agricultural fields.

We now consider the seasonal variation of DOC and POC (Figure 3). The mean concentrations of DOC and POC were highest in monsoon season (October 2009-December 2009) compared to post monsoon season (January 2010-September 2010). This is not surprising because during the heavy rainfalls, large amount of terrestrial organic matter are washed out into the rivers and discharged into wetland resulting in increased inputs of allochthonous organic matter as seen in other studies (Minor et al. 2006; Ribas-Ribas et al. 2011). In addition, strong current during the monsoon season probably contributed to resuspension of high organic matter from the bottom sediments. Lawrence et al. (2004) showed that strong wind and water current events will inject dissolved benthic materials from bottom sediment into the water column. In contrast, the decrease of DOC and POC concentration during post monsoon season may due to the decrease of terrestrial and freshwater inputs of water and DOC+POC (Ribas-Ribas 2011; Vittor et al. 2008).

\section{RELATIONSHIP BETWEEN DOC AND POC WITH Chl-a}

We now consider the role of internal production of DOC and POC. Chl- $a$ concentrations are typically used as a proxy for primary production (Rinker \& Powell 2006) and the organic carbon may also be associated with chl- $a$ (Kragh \& Søndergaard 2009). The relationship between DOC and POC with chl- $a$ is shown in Figure 4. There is no significant correlations between DOC and chl-a during monsoon $\left(\mathrm{R}^{2}=0.0255, n=30, p>0.05\right)$ or post monsoon season $\left(\mathrm{R}^{2}=0.0004, n=90, p>0.05\right)$. There was also no correlations of POC with chl- $a$ during monsoon $\left(\mathrm{R}^{2}=\right.$ $0.1455, n=30, p>0.05)$ and post monsoon $\left(\mathrm{R}^{2}=0.0442\right.$, $n=90, p>0.05)$. In contrast, a study by Zhang et al. (2009) in the eutrophic and shallow Taihu Lake, China showed there was significantly positive correlation $\left(\mathrm{R}^{2}\right.$ $=0.42, n=203, p<0.001)$ between dissolved organic matter (DOM) and chl- $a$, indicating that phytoplankton decomposition contributed to DOM concentration. Also the linear regression of POC and chl-a showed significant correlation in euphotic zone at the Southern East China, suggesting the in situ production was the dominant process controlling the $\mathrm{POC}$ in the euphotic layer of the water column (Hung et al. 2000). Suratman et al. (2009) also observed that there is significantly positively correlated between POC and chl- $a$ during autumn $\left(\mathrm{R}^{2}=\right.$ $0.23, p<0.05, n=35)$, spring $\left(\mathrm{R}^{2}=0.46, p<0.05, n=73\right)$ and summer $\left(\mathrm{R}^{2}=0.84, p<0.05, n=17\right)$, in the North Sea suggesting that the phytoplankton influenced the formation of POC for these three seasons.

\section{FRACTIONATION STUDY}

We now consider the distribution of DOC between the high and low molecular weight size fractions based on a molecular size cut off of $30 \mathrm{kDa}$. Figure 5 shows the mean percentage LMW DOC for selected sampling stations. The highest mean percentage of LMW DOC was recorded at station S10 with value $72 \pm 13 \%$. Meanwhile, the lowest mean percentage of LMW DOC was recorded at station S1 with value $68 \pm 12 \%$. For the other stations such as $S 3$, $\mathrm{S} 5$ and $\mathrm{S} 8$, the mean percentage recorded was $71 \pm 5 \%$, $69 \pm 11 \%$ and $70 \pm 9 \%$, respectively. In order to investigate the relationships between LMW DOC and chl- $a$, the linear regression graph between percentage LMW DOC against chl- $a$ for all the samples has been plotted as shown in Figure 6. The result showed low correlation $\left(\mathrm{R}^{2}=0.0096\right.$, $n=60, p>0.05$ ) between these two parameters suggesting that LMW DOC in this present study was not influenced by the phytoplankton. This observation was in contrast with those observed at other study areas as they found that most of the LMW DOC was through direct release from phytoplankton especially during the bloom (Guo et al. 2004; Suratman et al. 2009). For example, observation by Suratman et al.(2009) showed that the dominance of
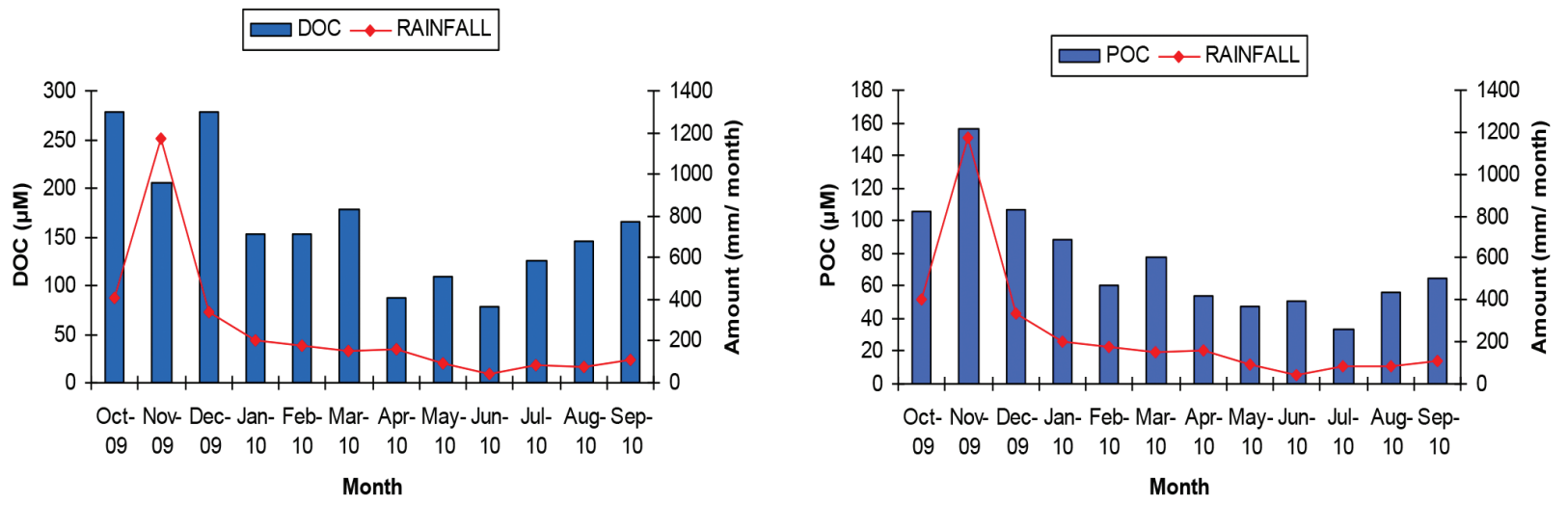

FIGURE 3. Seasonal variation of mean DOC and POC concentrations in Setiu Wetland 


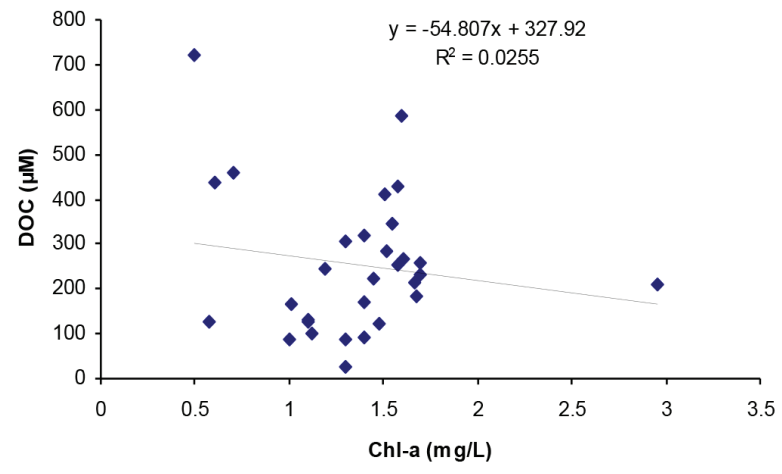

(a) Monsoon

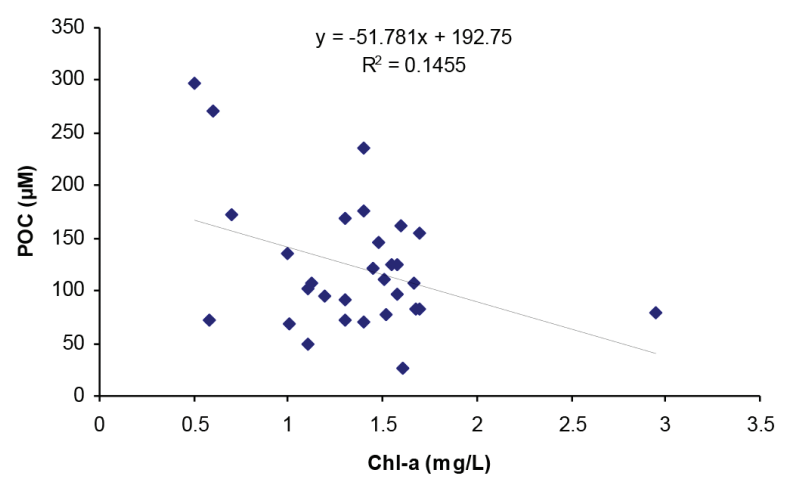

(a) Monsoon

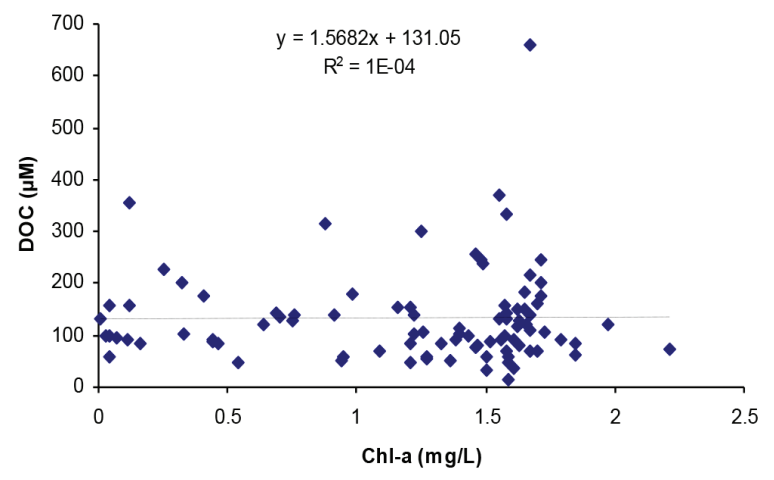

(b) Post Monsoon

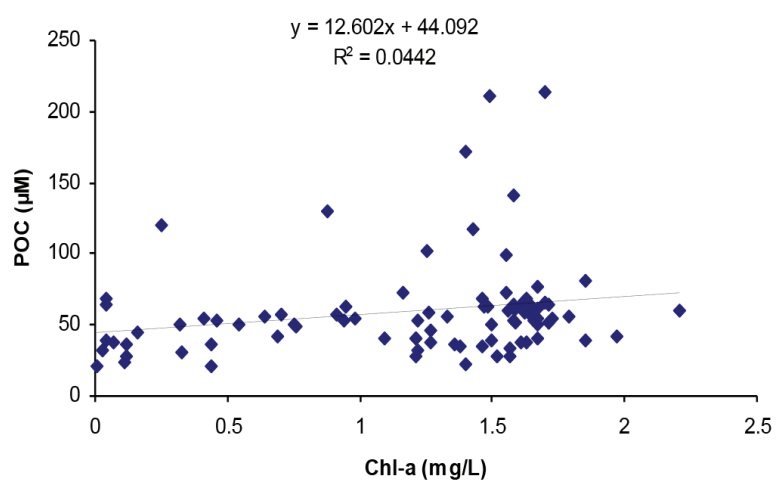

(b) Post Monsoon

FIGURE 4. Relationship between DOC and POC with chl-a during two seasons

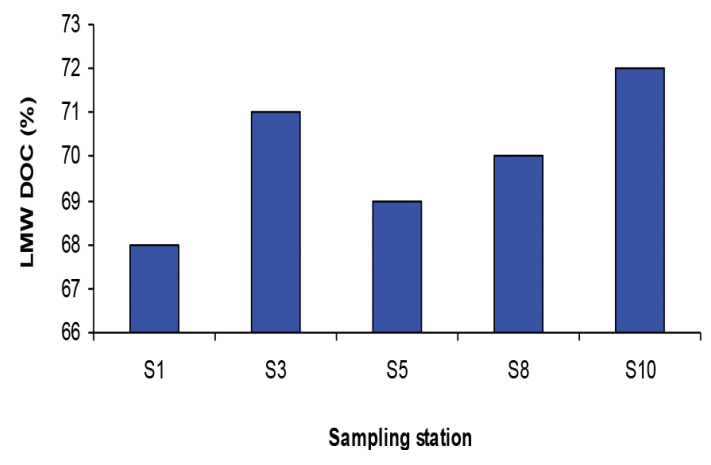

FIGURE 5. Variation of mean LMW DOC (\%) for five sampling stations

DOM by low-molecular weight compounds during spring season was released by the phytoplankton during bloom. The source of LMW DOC in this present study was unclear. The seasonal variation of the mean percentage LMW DOC for each month was plotted against the respective monthly rainfall (Figure 7). In general, higher mean percentage of LMW DOC was observed during monsoon season (October-December 2009) especially during the heavy rainfall which ranging between $73-80 \%$. This is consistent with the idea that high rainfall during monsoon resulted in increased runoff input of dissolved organic matter from land into the wetland which contained higher

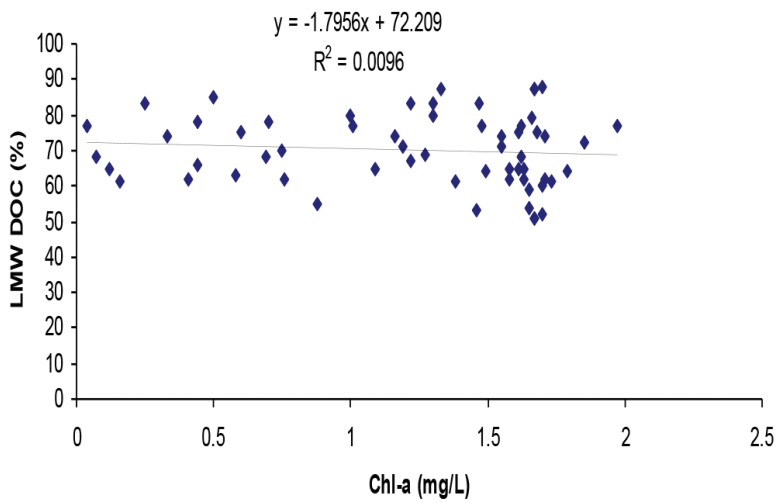

FIGURE 6. Relationship between LMW DOC with chl-a

LMW DOM. Meanwhile the mean percentage of LMW DOC starts to decrease when entering the post monsoon season (January-September 2010) ranging between 60$70 \%$ which may be due to low inputs of freshwater and associated DOC into the wetland.

\section{CONCLUSION}

The study showed that higher concentrations of DOC and POC were recorded at areas with high anthropogenic inputs such as untreated waste water, aquaculture and palm oil plantation. In addition, the runoff from land during heavy 


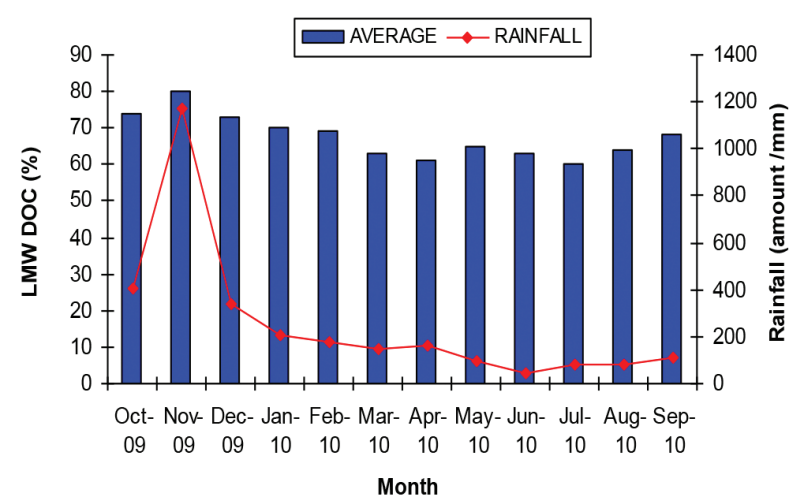

FIGURE 7. Variation of mean LMW DOC $(\%)$ with rainfall

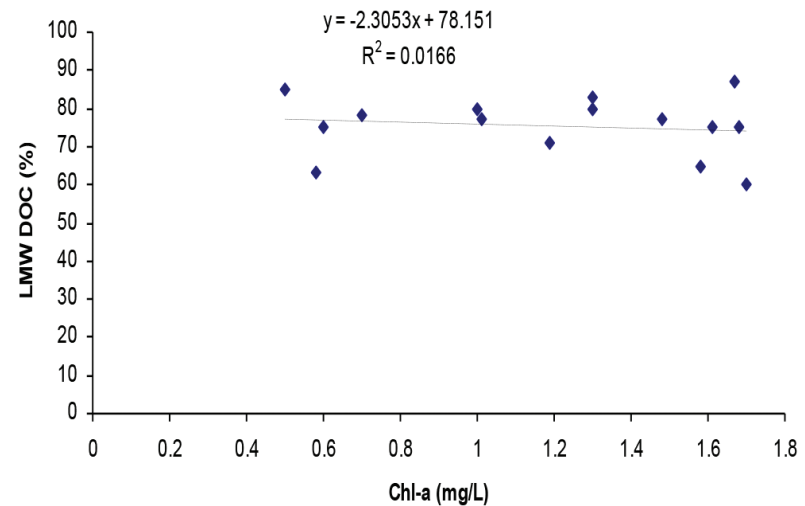

(a) Monsoon

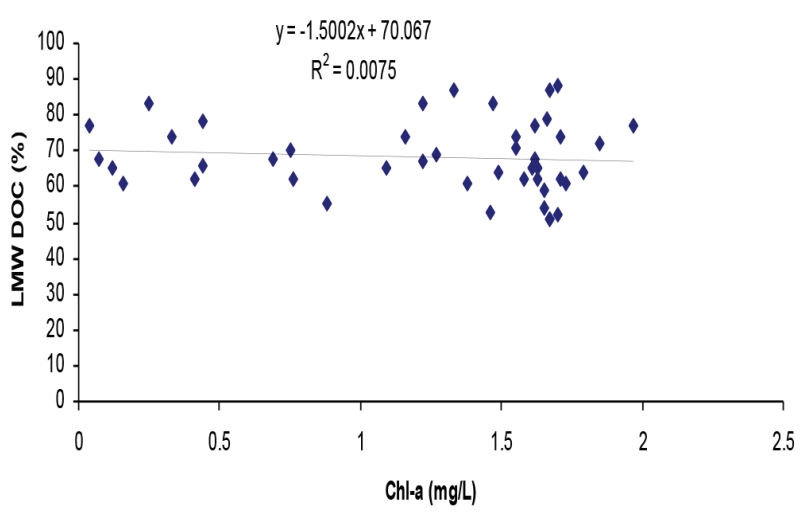

(b) Post Monsoon

FIGURE 8. Relationship between LMW DOC and chl-a during two seasons

rainfall also contributes to the high concentration of DOC and POC in monsoon season. No significant correlation was observed between DOC and POC with chl- $a$ concentrations, suggesting that the distribution of these nutrients is not controlled by phytoplankton as observed at other study areas. Low correlations between LMW DOC and chl- $a$ further support the contention that organic carbon in this area was not from the phytoplankton sources. Thus the cycle of DOC and POC in this lagoon at least is apparently dominated by external inputs rather than internal cycling. Therefore, further monitoring is needed in order to evaluate the human activity disturbance in this wetland.

\section{ACKNOWLEDGEMENTS}

This study was supported by the Ministry of Science, Technology and Innovation, Malaysia (Grant No. 04-0112-SF0085) and Higher Institution Centre of Excellence (HICoE) Research Program (Grant No. 66928) at the Institute of Oceanography and Environment, Universiti Malaysia Terengganu. Thanks to Prof. Tim Jickells (University of East Anglia, UK) for the improvements on the manuscript. This paper also benefited from the comments of anonymous reviewer.

\section{REFERENCES}

APHA 1998. Standard Methods for the Examination of Water and Wastewater. 20th ed. New York: America Public Health Association. p. 1067.

Avery, G.B., Kieber, R.J., Taylor, K.J. \& Dixon, J.L. 2012. Dissolved organic carbon release from surface sand of a high energy beach along the Southeastern Coast of North Carolina, USA. Marine Chemistry 132-133: 23-27.

Badr, E.S.A., Achterberg, E.P., Tappin, A.D., Hill, S.J. \& Braungardt, C.B. 2003. Determination of dissolved organic nitrogen in natural waters using high temperature catalytic oxidation. Trends in Analytical Chemistry 22: 819-827.

Bennett, S.A., Statham, P.J., Green, D.R.H., Bris, N.L., McDermott, J.M., Prado, F., Rouxel, O.J., Damm, K.V. \& German, C.R. 2011. Dissolved and particulate organic carbon in hydrothermal plumes from the East Pacific Rise, $9^{\circ} 50^{\prime} \mathrm{N}$. Deep-Sea Research I 58: 922-931.

Cai, Y., Guo, L., Wang, X., Mojzis, A.K. \& Redalje, D.G. 2012. The sources and distribution of dissolved and particulate organic matter in the Bay of St. Louis, northern Gulf of Mexico. Estuarine, Coastal and Shelf Science 96: 96-104.

Fernandes, L., Bhosle, N.B., Matondkar, S.G.P. \& Bhushan, R. 2009. Seasonal and spatial distribution of particulate organic matter in the Bay of Bengal. Journal of Marine Systems 77: 137-147. 
Gao, Q.F., Cheung, K.L., Cheung, S.U. \& Shin, P.K.S. 2005. Effects of nutrient enrichment derived from fish farming activities on macroinvertebrate assemblages in a subtropical region of Hong Kong. Marine Pollution Bulletin 51: 9941002 .

Goñi, M.A., Teixeira, M.J. \& Parkey, D.W. 2003. Sources and ditribution of organic matter in a river- dominated estuary (Winyah Bay, SC, USA). Estuarine, Coastal and Shelf Science 57: 1023-1048.

Graeber, D., Gelbrecht, J., Pusch, M.T., Anlanger, C. \& von Schiller, D. 2012. Agriculture has changed the amount and composition of dissolved organic matter in Central European headwater streams. Science of the Total Environment 438: 435-446.

Graham, M.C., Eaves, M.A., Farmer, J.G., Dobson, J. \& Fallick, A.E. 2001. A study of carbon and nitrogen stable isotope and elemental ratios as potential indicators of source and fate of organic matter in sediments of the Forth Estuary, Scotland. Estuarine, Coastal and Shelf Science 52: 375-380.

Guo, H.Y., Wang, X.R. \& Zhu, J.G. 2004. Quantification and index of non- point source pollution on Taihu Lake region with GIS. Environmental Geochemistry and Health 26: $147-156$

Hung, J.J., Lin, P.L. \& Liu, K.K. 2000. Dissolved and particulate organic carbon in the southern East China Sea. Continental Shelf Research 20: 545-569.

Hung, J.J., Wang, S.M. \& Chen, Y.L. 2007. Biogeochemical controls on the distributions and fluxes of dissolved and particulate organic carbon in the Northern South China Sea. Deep-Sea Research II 54: 1486-1503.

Jover, D.F., Jerez, P.S., Sempere, J.B., Carratala,A A \& Leon, V.M. 2007. Addition of dissolved nitrogen and dissolved organic carbon from wild fish feaces and food around Mediterranean fish farms: Implications for waste-dispersal models. Journal of Experimental Marine Biology and Ecology 340: 160-168.

Kragh, T. \& Søndergaard, M. 2009. Production and decomposition of new DOC by marine plankton communities: Carbohydrates, refractory components and nutrient limitation. Biogeochemistry 96: 177-187.

Lawrence, D., Dagg, M.J., Liu, H., Cummings, S.R., Ortner, P.B. \& Kelbie, C. 2004. Wind events and benthic-pelagic coupling in a shallow subtropical bay in Florida. Marine Ecology Progress Series 266: 1-13.

Li, F., Yuasa, A., Muraki, Y. \& Matsui, Y. 2005. Impacts of a heavy storm of rain upon dissolved and particulate organic $\mathrm{C}, \mathrm{N}$ and $\mathrm{P}$ in the main river of a vegetation-rich basin area in Japan. Science of the Total Environment 345: 99-113.

Lobbes, J.M., Fitznar, H.P. \& Kattner, G. 2000. Biogeochemical characteristics of dissolved and particulate organic matter in Russian rivers entering the Artic Ocean. Geochimica et Cosmochimica Acta 17: 2973-2983.

McKinnon, A.D., Trott, L.A., Brinkman, R., Duggan, S., Castine, S., O’Leary, A. \& Alongi, D.M. 2010. Sea cage aquaculture in a World Heritage Area: The environment footprint of a Barramundi farm in tropical Australia. Marine Pollution Bulletin 60: 1489-1501.

Meybeck, M. 1982. Carbon, nitrogen, and phosphorus transport by world rivers. American Journal of Science 282: 401-450.

Minor, E.C., Simjouw, J.P. \& Mulholland, M.R. 2006. Seasonal variations in dissolved organic carbon concentrations and characteristics in a shallow coastal bay. Marine Chemistry 101: 166-176.
Ribas-Ribas, M., Gomez-Parra, A. \& Forja, J.M. 2011. Spatiotemporal variability of the dissolved organic carbon and nitrogen in a coastal area affected by river input: The north eastern shelf of the Gulf of Cadiz (SW Iberian Peninsula). Marine Chemistry 126: 295-308.

Rinker, K.R. \& Powell, R.T. 2006. Dissolved organic phosphorus in the Mississippi River plume during spring and fall 2002. Marine Chemistry 102: 170-179.

Suratman, S., Jickells, T., Weston, K. \& Fernand,L. 2009. Spatial and seasonal changes of dissolved and particulate organic C in the North Sea. Hydrobiologia 628: 13-25.

Suratman, S., Mohd Tahir, N. \& Latif, M.T. 2012. A preliminary study of total petrogenic hydrocarbon distribution in Setiu Wetland, Southern South China Sea (Malaysia). Bulletin of Environmental Contamination and Toxicology 8: 755-758.

Vittor, C.D., Paoli, A. \& Umani, S.F. 2008. Dissolved organic carbon variability in a shallow coastal marine system (Gulf of Triete, northen Adriatic Sea). Estuarine, Coastal and Shelf Science 78: 280-290.

Wu, Y., Zhang, J., Liu, S.M., Zhang, Z.F., Yao, Q.Z., Hong, G.H. \& Cooper, L. 2007. Sources and distribution of carbon within the Yangtze River system. Estuarine, Coastal and Shelf Science 71: 13-25.

WWF. 2008. Sustainable Management of Setiu Wetlands. Available at: http://www.wwf.org.my. Accessed in February 2008.

Zhang, Y., van Dijk, M.A., Liu, M.,Zhu, G. \& Qin, B. 2009. The contribution of phytoplankton degradation to chromophoric dissolved organic matter (CDOM) in eutrophic shallow lakes: Field and experimental evidence. Water Research 43: 4685-4697.

Suhaimi Suratman*, Nur Hayati Che Zan, Azyyati Abdul Aziz \& Norhayati Mohd Tahir Institute of Oceanography and Environment Universiti Malaysia Terengganu 21030 Kuala Terengganu, Terengganu Darul Iman Malaysia

Suhaimi Suratman*

Institute for Kenyir Research

Universiti Malaysia Terengganu

21030 Kuala Terengganu, Terengganu Darul Iman

Malaysia

Norhayati Mohd Tahir

School of Marine Science and Environment

Universiti Malaysia Terengganu

21030 Kuala Terengganu, Terengganu Darul Iman Malaysia

*Corresponding author; email: miman@umt.edu.my

Received: 30 June 2016

Accepted: 24 November 2016 